\title{
Non-carcinogenic and Carcinogenic Risk Assessment of Heavy Metals Exposure to Indoor Dust in Kathmandu, Nepal
}

\section{Sulakshya Bhandari ${ }^{1}$, Sudarshana Shakya ${ }^{2}$, Bijaya Adhikari ${ }^{1}$, Mahesh Shrestha ${ }^{3}$, Bindra Devi Shakya $^{3}$, Achut Ram Pradhananga ${ }^{4}$, Prem Kumar Shrestha ${ }^{4}$, Ramesh Kaji Shakya ${ }^{5}$, Dipesh Raj Pant ${ }^{6}$, Pawan Raj Shakya ${ }^{4 *}$}

${ }^{1}$ Department of Environmental Science, Padma Kanya Multiple Campus, Tribhuvan University, Kathmandu, Nepal ${ }^{2}$ Department of Botany, Bhaktapur Multiple Campus, Tribhuvan University, Bhaktapur, Nepal ${ }^{3}$ Department of Mathematics and Statistics, Padma Kanya Multiple Campus, Tribhuvan University, Kathmandu, Nepal ${ }^{4}$ Department of Chemistry, Padma Kanya Multiple Campus, Tribhuvan University, Kathmandu, Nepal

${ }^{5}$ Department of Zoology, Padma Kanya Multiple Campus, Tribhuvan University, Kathmandu, Nepal

${ }^{6}$ Department of Environmental Science, Tri-Chandra Multiple Campus, Tribhuvan University, Kathmandu, Nepal

*CorrespondingE-mail: pawansh2003@yahoo.com

(Received: September 28, 2020; Revised: January 3, 2021; \& Accepted: January 5, 2021)

\begin{abstract}
The present study was carried out to assess the contamination of heavy metals in indoor household dust of Kathmandu, Nepal, and its adverse effect on the indoor environment and human health. The concentrations of four heavy metals $(\mathrm{Cd}, \mathrm{Cr}, \mathrm{Ni}$, and $\mathrm{Pb})$ in a total of ninety-three $(N=93)$ indoor dust samples collected from four different types of land use zones viz., commercial, heavy traffic, residential, and control (undisturbed) of Kathmandu were determined by the flame atomic absorption spectrophotometer (FAAS). The mean concentrations of $\mathrm{Cd}, \mathrm{Cr}, \mathrm{Ni}$, and $\mathrm{Pb}$ in indoor dust samples over the study zones were $0.89,158.1,113.3$, and $65.3 \mathrm{mg} / \mathrm{kg}$, respectively. The land use zones showed the various degree of metal contamination in indoor dust ranging from moderate to considerable level. PLI showed a high pollution load in the monitored locations, indicating an alarming condition and the urgent need for immediate remedial actions. Hazard quotient (HQ) values indicated ingestion as the major pathway of indoor dust heavy metal exposure to children while the inhalation pathway remained dominant in adults. Hazard index (HI) values showed no probable noncarcinogenic risk of the heavy metals present in the indoor dust of Kathmandu. For carcinogenic health risk, TLCR values were found within the acceptable safe limit indicating no cancer risk for both the receptor groups.
\end{abstract}

Keywords: Indoor dust, heavy metals, health risk, contamination assessment, Kathmandu

\section{Introduction}

In Kathmandu, the rapid growth in urbanization and industrialization has increased the risk of pollution due to dust particles in the indoor environment across different land use zones. Dust, a common air pollutant produced from various natural as well as anthropogenic activities, consists of solid particulate matter with fine particles [1]. Indoor air pollution with dust and other contaminants particularly toxic heavy metals may emanate from infiltration of outdoor pollutants, vehicle emission or through incense burning, smoking, furniture, and building materials or may result from occupants' activities [2]. Both outdoor and indoor dust are important (C) Nepal Chemical Society indicators of environmental contamination from the atmospheric deposition that receive varying inputs of anthropogenic metals from various stationary and mobile sources such as vehicular traffics, industrial activities, power plants, residential fossil fuel burning, waste incineration, construction, and demolition activities and re-suspension of contaminated soil [3, 4]. They are significant contributors to pollution in an urban environment.

Dust particles re-suspend in the atmosphere under certain meteorological conditions and accumulate either on roadsides or outdoor ground surfaces [5]. The most polluting heavy metals in the urban environment including $\mathrm{As}, \mathrm{Cd}, \mathrm{Co}, \mathrm{Cu}, \mathrm{Ni}, \mathrm{Zn}$, and 
$\mathrm{Pb}$, could be released via street dust to the underlying soil contaminating groundwater through rainwater or seepage [6]. Consequently, the natural biogeochemical cycle of the ecosystem is disrupted causing substantial risks to human health [7]. Therefore, heavy metals in dust particles require crucial study due to their peculiar characteristics such as non-biodegradable and persistent nature, long biological half-life, and their potential toxic effects on humans [8,9].

Dust particles less than $100 \mu \mathrm{m}$ size are more likely to stick on human skin and are harmful pollutants [10]. They can enter into the human body through three potential pathways viz., ingestion, dermal contact, and inhalation [11]. Heavy metals in dust particles are likely to affect children via ingesting dust through finger sucking and mouthing non-food objects [12]. It has been reported that people spend up to $90 \%$ of their time in indoor environments such as homes, schools, and offices [13,14]. The United States Environmental Protection Agency (USEPA) [13] has therefore raised special concern on indoor air because of its' more contaminating nature than outdoor air. According to WHO [15], nearly 4 million people die prematurely from non-communicable diseases including stroke, ischemic heart disease, chronic obstructive pulmonary disease (COPD), and lung cancer, attributable to household air pollution from inefficient cooking practices. Among them, inhalation of particulate matter (soot) causes nearly half of deaths among children less than 5 years of age due to pneumonia.

Kathmandu is the capital and largest municipality of Nepal which spreads over an area of $50.7 \mathrm{~km}^{2}$. The average elevation is 1,400 meters above sea level in the bowl-shaped Kathmandu Valley in central Nepal. The total population of Kathmandu city was 975,543 in the 2011 national census with an annual growth rate of $6.12 \%$ to the population figure of 2001 and projected to reach $1,319,597$ by 2021 . The local vehicular fleet has increased rapidly in recent years and the number of vehicles has exceeded 1.1 million in Kathmandu. The city, one of the fastest-growing metropolitan areas in South Asia with a 4 percent growth rate per year, has faced the unprecedented challenges of rapid urbanization and modernization at a metropolitan scale. Rapid urbanization and economic development in Kathmandu have resulted in a decline in its environmental quality. According to the WHO's Ambient Air Pollution Database [16], Kathmandu recorded the annual average $\mathrm{PM}_{2.5}$ concentration of $49 \mu \mathrm{g} / \mathrm{m}^{3}$ in 2013 , the value being 4.9 times higher than the maximum permissible limit recommended by WHO [17]. The levels of indoor and outdoor pollution in Kathmandu are therefore at great risk. Hence, the main objectives of this study are to (a) determine heavy metal contamination in indoor dust from different land-use zones across Kathmandu, (b) assess contamination level due to heavy metal accumulation in indoor dust, and (c) evaluate noncarcinogenic and carcinogenic health risks of heavy metals exposure to indoor dust in two receptor groups (children and adults) from the study areas.

\section{Materials and Methods}

\section{Sampling}

A total of 93 indoor household dust samples were collected from four different types of land use zones viz. commercial, heavy traffic, residential, and control (undisturbed area) in Kathmandu. The sampling sites were carefully selected to isolate the effect of metal discharges from different anthropogenic activities. For this, an initial field survey was made to enlist several potential sampling sites and categorized them under the above four major zones. The categorizations of sampling sites into four different land-use zones for indoor dust measurements were based on different domain activities in Kathmandu such as industrial, traffic load and population density, commercial, non-commercial and other anthropogenic activities. The sampling sites for indoor dust collection from different zones across Kathmandu are located using the GIS mapping method (Fig. 1).

From each land use category which was consecutively numbered for sampling indoor dust, 30 percent were selected following a simple lottery method. Accordingly, the number of sampling sites for the present study reached 9, 8, and 9 for commercial, heavy traffic, and residential zones respectively. The selection of control zone for background value was based on the sparse residential with low population density and limited anthropogenic activities. Our field observations also revealed no evidence of such domain activities in the past and during the sampling period as well. At the control zone, 5 sampling sites were selected for sample collection maintaining equidistance from one another. In this way, a total of 93 indoor dust samples (three households replicate from each sampling site) from adjacent to the roadside were collected during the dry season (FebruaryMarch, 2020). Dust samples were collected by gently sweeping an area of about $1 \mathrm{~m}^{2}$ from the residential 

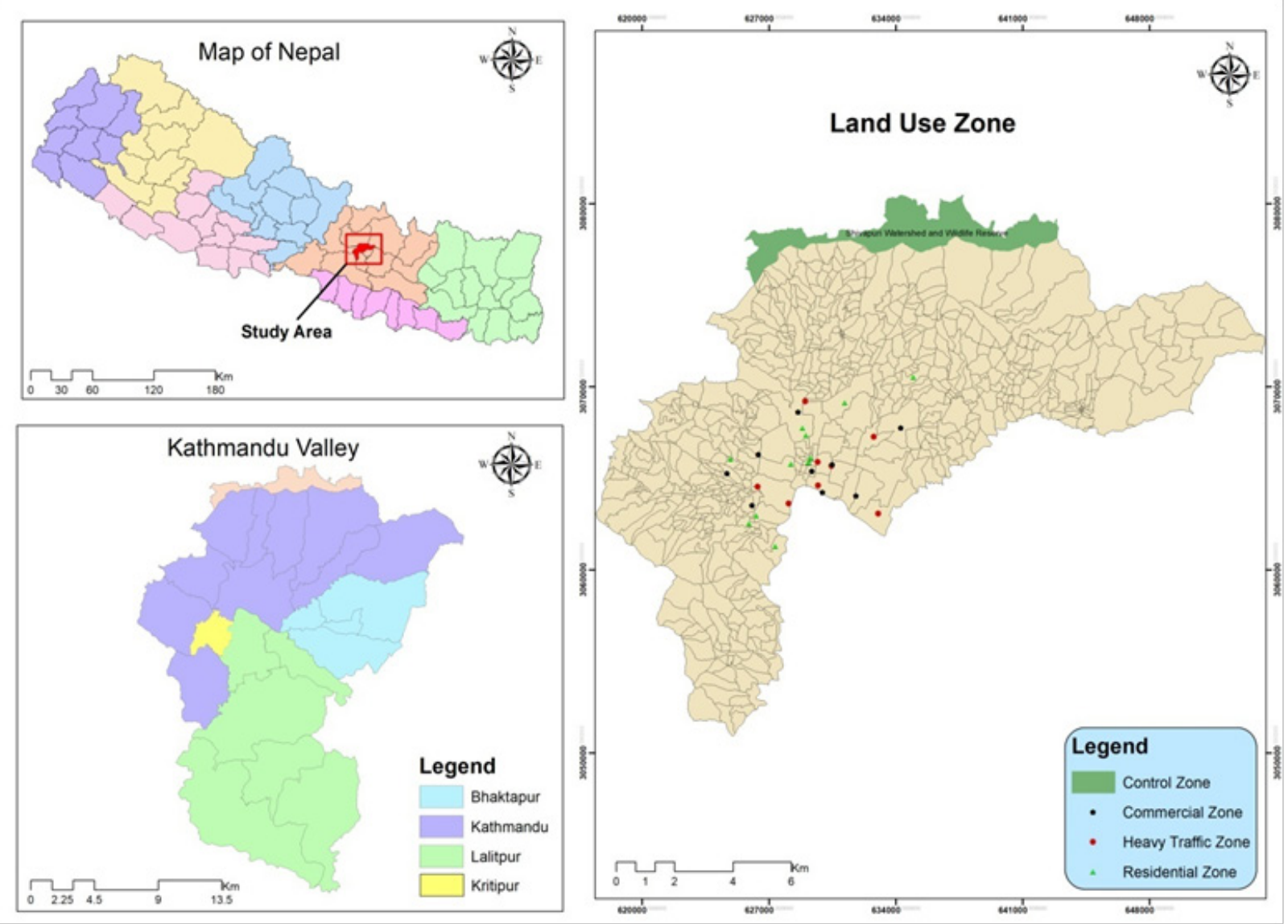

Figure 1: Location of the sampling sites representing different land-use zones in Kathmandu

floor, lamp covers, un-cleaned windowsills, and ceiling fans using a brush and plastic dustpan and transferring about $250 \mathrm{~g}$ of dust to self-sealing plastic bags and mixed as one sample to avoid comparison between the samples. The samples were well-labeled before transport to the laboratory. To avoid resuspension of the finest particles during sampling, the sweeping was made slow and collected directly into plastic bags.

\section{Sample preparation and analysis of heavy metals} In the laboratory, all samples were air-dried naturally for 3 weeks and then sieved initially through a 500$\mu \mathrm{m}$ mesh to remove pieces of stones, cigarette butts, dead organisms, and other unwanted fragments. Indoor dust with diameters below $100 \mu \mathrm{m}$ could be easily transported by re-suspension and accumulated from atmospheric deposition [18]. According to Shilton et al. [19], the finest particles of indoor dust can absorb high concentrations of heavy metals and remain airborne for a prolonged duration. Therefore, all dust samples were sieved through a sieve of 75 $\mu \mathrm{m}$ size for metal analysis. For determination of metal content, an aliquot of $0.5 \mathrm{~g}$ of dust sample was subjected to acid digestion using $10 \mathrm{~mL}$ concentrated $\mathrm{HNO}_{3}$ and $2 \mathrm{~mL} 70 \% \mathrm{HClO}_{4}$ over the hot plate at low temperature [20]. The digestion process was continued till the volume became 1-2 $\mathrm{mL}$, cooled, and then filtered through Whatman filter paper (No. 42) collecting the filtrate in a $25 \mathrm{~mL}$ volumetric flask. The interior of the beaker was washed two times with about $10 \mathrm{~mL}$ double distilled water, transferred into the funnel, and collected the filtrate into the same volumetric flask. The flask was mixed well to homogenize the sample and then the final volume was made with double distilled water. The samples were stored in the refrigerator at $4{ }^{\circ} \mathrm{C}$ before analysis or when not in use. The standard solutions of each heavy metal under investigation were prepared and used for calibration. The concentrations of four heavy metals $(\mathrm{Cd}, \mathrm{Cr}, \mathrm{Ni}$, and $\mathrm{Pb})$ were determined by the flame atomic absorption spectrophotometer (SOLAAR M5 Dual Atomizer, 180-900nm, Thermo Elemental, UK) using an air-acetylene flame. 


\section{Reagents, standards, and quality control}

All chemicals and reagents used in this study were of analytical grade and procured from Sigma-Aldrich, USA. The standard solutions $\left(1000 \mathrm{mgL}^{-1}\right)$ for $\mathrm{Cd}, \mathrm{Cr}$, $\mathrm{Ni}$, and $\mathrm{Pb}$, and standard reference materials (NIST SRM 1648) were certified and procured from FLUKA AG, Switzerland. The reagents and calibration standards were prepared by successive dilution using double distilled water. All the glassware was treated with dilute $(1: 1)$ nitric acid for $24 \mathrm{~h}$ and then rinsed with double distilled water before use. Quality assurance and quality control were assessed through the standard laboratory methods for the reliability of the analytical data. This process included the use of standard operating procedures for calibration techniques, analysis of reagent blanks, matrix spikes, replicates as well as preparation of standards. All analyses were carried out in triplicate, and the detection limit was determined as three times the standard deviation of the mean. The precision and analytical accuracy were checked by analysis of standard reference materials (NIST SRM 1648). The recovery percentage of metal concentrations from the reference materials was $98 \%(\mathrm{Cd}), 97 \%(\mathrm{Cr}), 98 \%$ $(\mathrm{Ni})$, and $98 \%(\mathrm{~Pb})$. To determine the precision of the analytical process, few samples from the sampling sites were analyzed by three times. The standard deviation for the pretested samples was calculated to be $2.1,2.3,2.6$, and $2.5 \%$ for $\mathrm{Cd}, \mathrm{Cr}, \mathrm{Ni}$, and $\mathrm{Pb}$ respectively, and can be considered satisfactory for the analysis of dust samples. The detection limits were found to be $0.1,1.0,0.1$, and $0.1 \mathrm{mg} / \mathrm{kg}$ for $\mathrm{Cd}$, $\mathrm{Cr}, \mathrm{Ni}$, and $\mathrm{Pb}$ respectively.

\section{Assessment of heavy metal contamination}

\section{Contamination factor and pollution load index}

To evaluate the level of contamination in an indoor environment, monitored through indoor dust, contamination factor $\left(C^{i} f\right)$ and pollution load index (PLI) were determined. Hakanson [21] reported four classes of contamination factor index $\left(C^{i f}\right)$ to evaluate the metal contamination levels. The metal contamination levels were classified as low for $C^{i f}$ $<1$, moderate for $1 \leq C^{i f}<3$, considerable for $3 \leq C^{i f}$ $<6$, and very high for $C^{i f} \geq 6$. The factor $C^{i f}$ can be calculated by Eq. 1:

$$
C^{i} f=\frac{C_{s}^{i}}{C_{b}^{i} \ldots \ldots \ldots \ldots \ldots \ldots(1)}
$$

where, $C^{i} S$ represents the mean concentration of heavy metal $i$ in the sample, and $C^{i} b$ denotes the reference concentration of heavy metal $i$. The metal concentration of indoor household dust from the control zone was considered as background value due to the unavailability of information for the background concentrations of metals in indoor dust.

The mutual pollution effect at different sampling sites by different metals was calculated using the pollution load index (Eq. 2). PLI is the geometric mean of the $C^{i f}$ values for the n metals [22].

$$
P L I=\left(C^{1} f \times C^{2} f \times C^{3} f \ldots \ldots \ldots \times C^{i} f\right)^{1 / i} \ldots
$$

where $i$ is the number of heavy metals, and $C^{i f}$ is the contamination factor calculated by Eq.1. The PLI method can simply assess the site quality by identifying three classifications, viz., no pollution for PLI $<1$, deterioration of site quality for PLI $>1$, and baseline levels of pollutants for PLI $=1$ [22].

\section{Human health risk assessment (HRA)}

Risk assessment of human health is an important tool and extensively implemented for characterizing heavy metals along with their exposure pathways (Ingestion, dermal contact, and inhalation) in urban environments. The methodology used for the health risk assessment was based on the guidelines following the Exposure Factors Handbook of the US Environmental Protection Agency (USEPA) [13,23-25] and Ontario (Canada) Ministry of the Environment (OME) protocols [26].

\section{Non-carcinogenic risk}

Average daily dose (ADD) ( $\mathrm{mg} / \mathrm{kg}$ /day) of potentially toxic heavy metals that affect children and adults via ingestion $\left(\mathrm{ADD}_{\text {ingest }}\right)$, dermal contact $\left(\mathrm{ADD}_{\text {dermal }}\right)$, and inhalation $\left(\mathrm{ADD}_{\text {inhale }}\right)$ were estimated using the following Eqs. (3-5).

$$
\begin{aligned}
& A D D(\text { ingest })=\frac{C \times I n g R \times E F \times E D \times C F}{B W \times A T} \ldots \ldots \ldots \ldots \ldots(3) \\
& A D D(\text { dermal })=\frac{C \times S A \times A F \times A B S \times E F \times E D \times C F}{B W \times A T} \ldots \ldots \ldots \ldots \ldots(4) \\
& A D D(\text { inhale })=\frac{C \times \operatorname{Inh} R \times E F \times E D}{P E F \times B W \times A T} \quad \ldots \ldots \ldots \ldots \ldots(5)
\end{aligned}
$$

where, $\mathrm{C}$ is the concentration of heavy metals (mg/ $\mathrm{kg}$ ); IngR, the ingestion rate (mg/day); SA, the surface area of the skin exposed to heavy metal $\left(\mathrm{cm}^{2}\right)$; AF, the skin adherence factor $\left(\mathrm{mg} / \mathrm{cm}^{2} /\right.$ day $)$; ABS, the dermal absorption factor $\left(\mathrm{mg} / \mathrm{cm}^{2}\right)$; InhR, the inhalation rate $\left(\mathrm{m}^{3} /\right.$ day); $\mathrm{PEF}$, the particle emission factor $\left(\mathrm{m}^{3} /\right.$ $\mathrm{kg}$ ); EF, the exposure frequency (days/year); ED, the exposure duration (year); BW, the body weight $(\mathrm{kg})$; $\mathrm{AT}$, the averaging time (days); and CF, the conversion factor. 
C (exposure-point concentration, $\mathrm{mg} / \mathrm{kg}$ ) in Eqs. (35), combined with the values for the exposure factors shown above, is considered to yield an estimate of the "reasonable maximum exposure" [27], which is the upper limit of $95 \%$ confidence interval of the mean. The $95 \%$ upper confidence limit (UCL) was calculated as shown in Eq. (6).

$$
\text { If } \left.(n \geq 30), \quad U C L=\bar{X} \pm Z \frac{\alpha}{2}\left(\frac{\sigma}{\sqrt{n}}\right) \ldots \ldots \ldots 6\right)
$$

where, $\mathrm{n}=$ sample quantity, $\overline{\mathrm{X}}=$ arithmetic mean concentration, $\sigma=$ standard deviation, $\alpha=1-$ (confidence level/100), $Z_{\alpha / 2}=Z$-table value, and $\mathrm{UCL}=$ upper confidence limit.

The receptor parameters used in the present study (Table 1) are based on US Environmental Protection Agency (USEPA) [23] and Ontario (Canada) Ministry of the Environment (OME) protocols [26].

Table 1: Receptor parameters for risk assessment

\begin{tabular}{|c|c|c|c|c|}
\hline \multirow[t]{2}{*}{ Factor } & \multirow[t]{2}{*}{ Definition } & \multirow[t]{2}{*}{ Unit } & \multicolumn{2}{|c|}{ Receptor } \\
\hline & & & Children & Adults \\
\hline $\mathrm{IR}_{\text {ingest }}$ & Ingestion rate & g/day & 0.1 & 0.02 \\
\hline $\mathrm{IR}_{\text {inhale }}$ & Inhalation rate & $\mathrm{m}^{3} /$ day & 12.0 & 50.0 \\
\hline PEF & $\begin{array}{l}\text { Particle emission } \\
\text { factor }\end{array}$ & $\mathrm{m}^{3} / \mathrm{kg}$ & $1.36 \times 10^{9}$ & $1.36 \times 10^{9}$ \\
\hline SA & Exposed skin area & $\mathrm{m}^{2}$ & 0.586 & 1.03 \\
\hline $\mathrm{AF}$ & $\begin{array}{l}\text { Skin adherence } \\
\text { factor }\end{array}$ & $\mathrm{mg} / \mathrm{cm}^{2}$ & 0.02 & 0.07 \\
\hline $\mathrm{ABS}$ & $\begin{array}{l}\text { Dermal absorption } \\
\text { factor }\end{array}$ & - & 0.01 & 0.01 \\
\hline ED & Exposure duration & year & 7.0 & 50.0 \\
\hline $\mathrm{EF}$ & Exposure frequency & day/yr & 320 & 350 \\
\hline BW & Average body weight & $\mathrm{kg}$ & 32.9 & 70.7 \\
\hline AT & $\begin{array}{l}\text { Average lifetime for } \\
\text { heavy metals }\end{array}$ & day & $\mathrm{ED} \times 365$ & $\mathrm{ED} \times 365$ \\
\hline
\end{tabular}

The reference dose of the elements (Table 2) for three different pathways and slope factor for different elements used in the present study were adapted from USEPA [25].

Table 2: Reference dose (RfD, $\mathrm{mg} / \mathrm{kg} /$ day) of elements for three different pathways and slope factor values $\left(\mathrm{SF},(\mathrm{mg} / \mathrm{kg} / \mathrm{day})^{-1}\right)$

\begin{tabular}{lllll}
\hline Pathways & $\mathbf{C d}$ & $\mathbf{C r}$ & $\mathbf{N i}$ & $\mathbf{P b}$ \\
\hline Oral RfD & $1.00 \times 10^{-3}$ & $3.00 \times 10^{-3}$ & $2.00 \times 10^{-2}$ & $3.50 \times 10^{-3}$ \\
Dermal RfD & $5.00 \times 10^{-5}$ & $6.00 \times 10^{-5}$ & $5.40 \times 10^{-3}$ & $5.30 \times 10^{-4}$ \\
Inhal. RfD & $1.00 \times 10^{-3}$ & $2.86 \times 10^{-5}$ & $2.06 \times 10^{-2}$ & $3.50 \times 10^{-3}$ \\
Slope factor (SF) & 6.3 & 0.5 & 4.4 & $8.50 \times 10^{-3}$ \\
\hline
\end{tabular}

The non-carcinogenic effects of heavy metals were estimated by calculating the hazard quotient (HQ) and hazard index (HI), using Eqs. (7-8):

$$
\mathrm{HQ}=\mathrm{ADD} / \mathrm{RfD}
$$

$$
\mathrm{HI}=\mathrm{HQ}(\text { ingest })+\mathrm{HQ}(\text { dermal) }+\mathrm{HQ} \text { (inhale) }
$$

The HQ for children and adults during a lifetime was calculated by dividing the ADD from each exposure pathway by a specific RfD as shown in Eq. (7). Here, ADD is the average daily dose and RfD is the estimated maximum permissible risk posed to the human population (for both children and adults) through daily exposure to a particular metal, without causing a considerable risk of deleterious impacts during a lifetime [28]. According to USEPA [24, 27], no risk of adverse health effects occurs for HQ $\leq 1$, and there will be a probability of adverse health effects for $\mathrm{HQ}>1$.

Hazard index is used to evaluate the potential risk to human health when more than one heavy metal is involved. Hazard index is calculated as the sum of hazard quotients (HQs) as shown in Eq. 8 [28]. There is no risk of non-carcinogenic impacts for $\mathrm{HI} \leq 1$, and a chance of negative health effects occurs for $\mathrm{HI}>1$ [29].

\section{Carcinogenic risk}

According to Li et al. [30], lifetime carcinogenic risk (LCR) denotes the probability of an individual developing any type of cancer over a lifetime due to carcinogenic exposures. The LCR of children and adults caused by potential carcinogen exposure over a lifetime is estimated using Eq. (9) for average daily dose (ADD in $\mathrm{mg} / \mathrm{kg} /$ day) multiplied by the cancer slope factor (SF) for each exposure [31]. Equation (10) shows the total lifetime carcinogenic risk (TLCR) that adds up all LCRs calculated for ingestion, dermal contact, and inhalation.

$$
\mathrm{LCR}=\mathrm{ADD} \times \mathrm{SF}
$$

TLCR $=$ LCR (ingest) + LCR (dermal) + LCR (inhale)

The acceptable value of TLCR for carcinogenic risk is in the range of $1 \times 10^{-6}-1 \times 10^{-4}$ [23]. If the risk exceeds the range, this implies that carcinogenic risks exist and the potential carcinogenic effect would likely occur.

\section{Statistical analysis}

An IBM-PC computer was used for all data processing including descriptive statistics such as frequency, percentage, mean and standard deviation. SPSS v.19.0 (SPSS Inc., Chicago, USA) was used to study correlation among the metals.

\section{Results and Discussion}

Heavy metal concentrations in indoor dust

Table 3 lists the range and mean of heavy metal concentrations $(\mathrm{Cd}, \mathrm{Cr}, \mathrm{Ni}$, and $\mathrm{Pb})$ in indoor dust determined at different land-use zones in Kathmandu. 
Table 3: Heavy metal concentration $(\mathrm{mg} / \mathrm{kg})$ in indoor dust (Mean $\pm S D)$ from different landuse zones of Kathmandu

\begin{tabular}{llllll}
\hline Land use zone & Statistical parameter & $\mathbf{C d}$ & $\mathbf{C r}$ & $\mathbf{N i}$ & $\mathbf{P b}$ \\
\hline Commercial zone $(\mathrm{n}=9)$ & Mean & $0.88 \pm 0.17$ & $175.4 \pm 44.7$ & $132.3 \pm 37.6$ & $48.4 \pm 20.1$ \\
& Range & $0.64-1.12$ & $97.3-245.4$ & $75.5-188.7$ & $20.8-76.3$ \\
Heavy traffic zone $(\mathrm{n}=8)$ & Mean & $1.00 \pm 0.22$ & $158.7 \pm 48.0$ & $114.2 \pm 23.8$ & $97.8 \pm 20.5$ \\
& Range & $0.62-1.32$ & $85.5-231.8$ & $72.9-155.2$ & $65.6-130.0$ \\
\multirow{2}{*}{ Residential zone (n=9) } & Mean & $0.80 \pm 0.22$ & $140.3 \pm 60.1$ & $93.3 \pm 17.8$ & $49.6 \pm 9.0$ \\
& Range & $0.63-1.15$ & $68.2-212.4$ & $68.2-118.4$ & $36.8-62.5$ \\
Kathmandu District & Mean of all land use & 0.89 & 158.1 & 113.3 & 65.3 \\
\multirow{2}{*}{ Control zone (n=5) } & zones & $0.39 \pm 0.11$ & $76.3 \pm 19.9$ & $32.8 \pm 9.6$ & $38.0 \pm 10.5$ \\
& Mean & $0.24-0.54$ & $50.1-102.4$ & $20.7-45.9$ & $25.3-51.0$ \\
\multirow{2}{*}{ World's average shale values } & Range & 0.3 & 90.0 & 68.0 & 20.0 \\
\hline
\end{tabular}

Table 3 also presents the world average shale values of each heavy metal under investigation [32]. The mean concentrations of $\mathrm{Cd}, \mathrm{Cr}, \mathrm{Ni}$, and $\mathrm{Pb}$ in indoor dust samples over the study zones were $0.89,158.1,113.3$, and $65.3 \mathrm{mg} / \mathrm{kg}$ respectively. Chromium retained the highest mean concentration among heavy metals followed by $\mathrm{Ni}, \mathrm{Pb}$, and $\mathrm{Cd}$ (Table 3 ). The values were comparably higher than their control zone as well as the world's average shale values. Further, the results revealed that the mean concentration of heavy metals in the dust samples from the commercial, heavy traffic, and residential zones was in the order of $\mathrm{Cr}>\mathrm{Ni}>\mathrm{Pb}>\mathrm{Cd}$. The increase of $\mathrm{Cr}$ concentration could be attributed to its use in many alloys, especially stainless steel; therefore, grinding, welding, and also polishing of stainless steel can lead to the discharge of this element into the indoor environment [33]. Anthropogenically, $\mathrm{Cr}$ occurs by the burning of oil and coal, chromium steel, metal plating tanneries and also through sewage and fertilizers [34]. Apart from this, the source of $\mathrm{Cr}$ and $\mathrm{Ni}$ in dust is believed to be from car components, tyre abrasion, lubricants, engine wear, thrust bearing, brake dust, and bearing metals [35]. The highest concentration of $\mathrm{Ni}$ was recorded in indoor dust from the commercial zone followed by heavy traffic and residential zones. Nickel is representative metal of anthropogenic activities including machining, coal combustion, metallurgy and so on. The source of $\mathrm{Ni}$ in dust is also believed to be from corrosion of cars [36]. The metal is used for plating the outer part of a vehicle, such as the tyre rims or as an alloy for plating the surface of the cylinder and pistons of an engine.
The highest concentration of $\mathrm{Pb}$ was observed in the heavy traffic zone followed by residential and commercial zones. Lead is a major pollutant in the indoor environment that is released from combustion of gasoline containing $\mathrm{Pb}$, burning gas for heating, road paints, abrasion of the automobile tyres, engine wear, radiators, leaks, and spills from batteries [37]. Although leaded petrol is banned in many countries today including Nepal, significant archives may still exist in the near-road environment as the low solubility of $\mathrm{Pb}$ allows it to have long residence times in the soil column [38].

Although $\mathrm{Cd}$ was found in lowest concentration among the heavy metals, heavy traffic zone showed the highest contamination of $\mathrm{Cd}$ in its indoor dust samples among the three major land use zones. Cadmium that occurs naturally in combination with zinc is a relatively rare heavy metal. Motor vehicles, car and automobile lubricants and reinforced car tyres with metals $(\mathrm{Zn})$ are the possible source for $\mathrm{Cd}$ emissions in dust [39].

Table 4: Pearson's correlation coefficients among heavy

\begin{tabular}{ccccc}
\multicolumn{5}{c}{ metals } \\
\hline & $\mathbf{C d}$ & $\mathbf{C r}$ & $\mathbf{N i}$ & $\mathbf{P b}$ \\
\hline $\mathrm{Cd}$ & 1.00 & 0.214 & 0.218 & $\mathbf{0 . 8 1 2 *}$ \\
$\mathrm{Cr}$ & 0.214 & 1.00 & $\mathbf{0 . 7 8 4} *$ & 0.316 \\
$\mathrm{Ni}$ & 0.218 & $\mathbf{0 . 7 8 4} *$ & 1.00 & 0.214 \\
$\mathrm{~Pb}$ & $\mathbf{0 . 8 1 2 *}$ & 0.316 & 0.214 & 1.00
\end{tabular}

*The correlation is significant at the 0.05 level.

The anthropogenic sources of $\mathrm{Cd}$ in dust are reportedly originated from automotive emissions, corrosion of the brake lining, the wear and tear as well as burning 
Table 5: Comparison of heavy metals concentration in indoor dust in this study with previous studies across the world $(\mathrm{mg} / \mathrm{kg})$

\begin{tabular}{llllll}
\hline Cities/Countries & $\mathbf{C d}$ & $\mathbf{C r}$ & $\mathbf{N i}$ & $\mathbf{P b}$ & References \\
\hline Kathmandu/Nepal & 0.89 & 158.12 & 113.26 & 65.27 & Present study \\
Khorramabad/Iran & 11.34 & 11.81 & 60.19 & 32.08 & Sabzevari \& Sobhanardakani [33] \\
Cairo/Egypt & 1.73 & 78.40 & 31.63 & 181.26 & Hassan [43] \\
Anhui/China & - & 113.68 & 38.93 & 348.73 & Lin et al. [45] \\
Istanbul/Turkey & 0.8 & 55.0 & 263.0 & 28.0 & Kurt-Karakus [46] \\
Al-Karak city/Jordan & - & 65.5 & 17.9 & 81.15 & Madanat et al. [47] \\
Ebedei/Nigeria & 4.8 & - & 20.15 & 97.45 & Boisa \& Odagwe [48] \\
Bushehr/Iran & 5.4 & 83.5 & 42.0 & 93.4 & Ardashiri \& Hashemi [49] \\
Colombo/Sri Lanka & - & 0.8 & - & 2.3 & Pitawala et al. [50] \\
\hline
\end{tabular}

of vehicle tyres $[36,40]$. Cadmium is also used as an attendant substance of the zinc oxide in rubber matrix. Besides, domestic use of coal for cooking as well as burning of household refuse and products (batteries, toys, cigarettes, etc.) is another prominent source of $\mathrm{Cd}$.

Table 4 shows correlations among the heavy metals under the present investigation. The positive correlations among the heavy metals indicate their common sources [41] and are frequently expressed by Pearson's correlation coefficient. The strong correlation was observed between $\mathrm{Cd}$ and $\mathrm{Pb}(\mathrm{r}=$ $0.812, \mathrm{p}<0.05)$, and $\mathrm{Cr}$ and $\mathrm{Ni}(\mathrm{r}=0.784, \mathrm{p}<0.05)$ implying probably similar characteristics, fate and share common origins of emission. Moreover, the results revealed positive correlations, though not much significant, among the parameters suggesting common contaminant sources.

Although heavy metals in dust could be derived from indoor and outdoor sources, the result of this study indicated major influence from outdoor sources. The possible routes of heavy metals entering the household buildings could be through the open windows for cooling and ventilation [42]. While recognizing the fact that the movement of people in and out from houses also contributes the heavy metals inside the houses, its contribution is obvious from the ambient sources [9]. In addition, Hassan [43] found a high concentration of metals at house entryways due to footsteps carrying outdoor dust into an indoor environment. Besides, the study also revealed increasing concentrations of $\mathrm{Pb}, \mathrm{Ni}, \mathrm{Cd}, \mathrm{Co}, \mathrm{Cu}$ and $\mathrm{Cr}$ with decreasing size of dust particles because a smaller dust particle has a larger surface area and hence can absorb greater amount of metals [43]. Latif et al. [44] also found wind-blown dust from surface soil and road dust as the main contributors of heavy metal contents found in indoor dust.
Status of indoor environment (heavy metal pollution) in Kathmandu: Comparison with studies across the world

The mean concentrations of heavy metals in indoor dust in the present study were compared against different cities/countries across the world with a view to evaluate the status of indoor environment due to heavy metal exposure in indoor dust in Kathmandu (Table 5).

The mean level of $\mathrm{Cd}(0.89 \mathrm{mg} / \mathrm{kg})$ as observed in the present study was comparable with the value reported from Istanbul (Turkey) but was lower than Khorramabad (Iran), Ebedei (Nigeria), Busheher (Iran) and Cairo (Egypt). On the contrary, the present study recorded exceptionally the highest level of $\mathrm{Cr}$ in indoor household dust compared to the list of cities/countries under study (Table 6). With the exception of Istanbul (Turkey), the mean level of $\mathrm{Ni}$ in the present study was comparatively higher than those reported for Khorramabad (Iran), Anhui (China), Cairo (Egypt), Al-Karak city (Jordan), Ebedei (Nigeria) and Busheher (Iran). Similarly, $\mathrm{Pb}$ level was found to be higher than Khorramabad (Iran), Istanbul (Turkey) and Colombo (Sri Lanka) but lower than those reported for Anhui (China), Cairo (Egypt), Al-Karak city (Jordan), Ebedei (Nigeria) and Busheher (Iran). The interplay of sources of metals, land use type, traffic volume, fuel quality, distance from the road, building materials, human habits, populations, etc. in each city determines the metal concentration in dust [51]. Hence, it may be suggested that degree of heavy metals contamination in indoor dust in a particular location or area depends mainly on the level and types of anthropogenic activities there.

\section{Assessment of heavy metal contamination in indoor dust \\ Contamination factor and pollution load index}

The land use-wise distribution of contamination and pollution load in indoor dust by $\mathrm{Cd}, \mathrm{Cr}, \mathrm{Ni}$ and $\mathrm{Pb}$ is presented in Table 6 and their classifications based 
Table 6: Contamination factor (CF) and pollution load index (PLI) of different land use zones in Kathmandu

\begin{tabular}{lcccc}
\hline Contamination factor (CF) \\
\cline { 2 - 5 } Landuse & \multicolumn{4}{c}{ Heavy metals } \\
\cline { 2 - 5 } zone & $\mathrm{Cd}$ & $\mathrm{Cr}$ & $\mathrm{Ni}$ & $\mathrm{Pb}$ \\
\hline Commercial & 2.26 & 2.30 & 4.03 & 1.27 \\
Heavy traffic & 2.56 & 2.08 & 3.48 & 2.57 \\
Residential & 2.05 & 1.84 & 2.85 & 1.31 \\
\hline Pollution load index (PLI) \\
\hline Landuse \\
zone & PLI value \\
\hline Commercial & & \\
Heavy traffic & 5.16 \\
Residential & 6.90 \\
\hline
\end{tabular}

on contamination levels are shown in Table 7.The contamination factor (CF) indicates the amount of anthropogenically introduced metal in dust with respect to the natural concentration.

Table 6 showed that the contamination factor for $\mathrm{Ni}$ was found to be comparatively higher among the metals analyzed in indoor dust and in all land use zones in the order of commercial (4.03) > heavy traffic (3.48) > residential (2.85). Similar trend was also exhibited by all the land use zones for Cr. The heavy traffic zone showed higher contamination factor for $\mathrm{Cd}$ (2.56) and $\mathrm{Pb}$ (2.57) compared to the rest of the land use zones. Evidently, the commercial and heavy traffic zones showed considerable level of contamination $(3 \leq \mathrm{CF}<6)$ for $\mathrm{Ni}($ Table 7$)$ whereas the residential zone exhibited moderate level of contamination $(1 \leq \mathrm{CF}<3)$ for the same metal based on their contamination factors. On the other side, the moderate level of contamination $(1 \leq \mathrm{CF}<3)$ was observed for $\mathrm{Cd}, \mathrm{Cr}$ and $\mathrm{Pb}$ in indoor dust from the commercial, heavy traffic and residential land use zones.

The average metal contamination level in Kathmandu which is the ratio of average metal concentration from all land use zones to the metal concentration from control zone is presented in Figure 2.

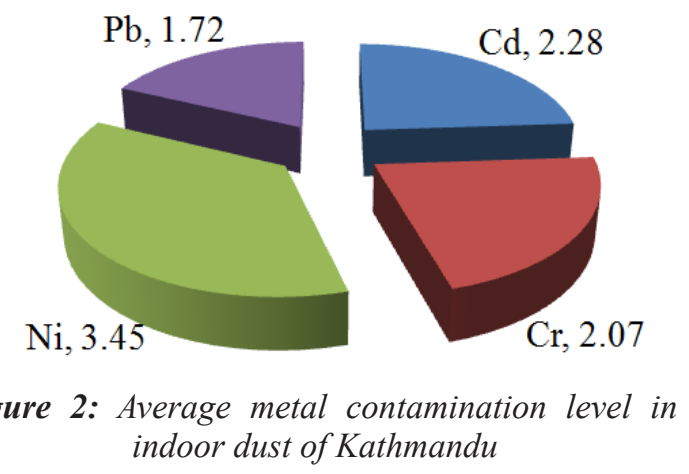

Based on the average metal concentration from all land use zones and the average contamination level calculated thereafter, it can be concluded that average metal contamination level in indoor household dust from Kathmandu is at considerable level of contamination for $\mathrm{Ni}(\mathrm{CF}=3.45)$ and moderate level for $\mathrm{Cd}(\mathrm{CF}=2.28), \mathrm{Cr}(\mathrm{CF}=2.07)$ and $\mathrm{Pb}(\mathrm{CF}=$ 1.72) (Figure 2). Accordingly, the average metal contamination level in indoor dust from Kathmandu follows the order of $\mathrm{Ni}>\mathrm{Cd}>\mathrm{Cr}>\mathrm{Pb}$.

Pollution load index (PLI) demonstrates the mutual pollution effect in dust by different metals. Table 6 showed high PLI values indicating high pollution load in all the monitored land use zones. All the land use zones were found to have a category of polluted dust (PLI > 1) based on their PLI classification (Table $7)$. Results revealed that the heavy traffic zone was found to have a comparatively higher PLI value (6.90) followed by commercial (5.16) and residential (3.75) zone respectively. The high PLI could be attributable to the cumulative concentrations of heavy metals in contamination factor and pollution load index Table 7: Classification of pollution indices based on contamination facto
of different land use zones in Kathmandu

\begin{tabular}{|c|c|c|c|c|}
\hline \multicolumn{5}{|c|}{ Pollution index (Contamination factor) } \\
\hline Land use zone & $\begin{array}{c}\text { Low } \\
(\mathrm{CF}<1)\end{array}$ & $\begin{array}{c}\text { Moderate } \\
(1 \leq \mathrm{CF}<3) \\
\end{array}$ & $\begin{array}{c}\text { Considerable } \\
(3 \leq \mathrm{CF}<6)\end{array}$ & $\begin{array}{c}\text { Very High } \\
(6 \leq \mathrm{CF})\end{array}$ \\
\hline Commercial & - & $\mathrm{Cd}, \mathrm{Cr}, \mathrm{Pb}$ & $\mathrm{Ni}$ & - \\
\hline Heavy traffic & - & $\mathrm{Cd}, \mathrm{Cr}, \mathrm{Pb}$ & $\mathrm{Ni}$ & - \\
\hline Residential & - & $\mathrm{Cd}, \mathrm{Cr}, \mathrm{Ni}, \mathrm{Pb}$ & - & - \\
\hline \multicolumn{5}{|c|}{ Pollution index (Pollution load index) } \\
\hline Land use zone & & $\begin{array}{l}\text { ted dust } \\
(I>1)\end{array}$ & \multicolumn{2}{|c|}{$\begin{array}{c}\text { Non-polluted dust } \\
(\text { PLI }<1)\end{array}$} \\
\hline Commercial & & $(+)$ & \multicolumn{2}{|c|}{-} \\
\hline Heavy traffic & & $(+)$ & \multicolumn{2}{|c|}{-} \\
\hline Residential & & $(+)$ & \multicolumn{2}{|c|}{-} \\
\hline
\end{tabular}


all land use zones, implying an alarming condition. The results of the present study are also in agreement with Roy et al. [20], Dehghani et al. [52] and Mehr et al. [53] who also reported high pollution load in dust in their studies highlighting that the highly contaminated areas are mostly affected by pollution from traffic, industries and other indoor and outdoor anthropogenic activities.

\section{Human health risk assessment}

The health risks due to heavy metals exposure in indoor dust included non-carcinogenic and carcinogenic. The assessment was done for children and adults as two receptor groups.

\section{Non-carcinogenic risk}

Non-carcinogenic risks from the HMs in indoor dust for three different exposure pathways (ingestion, dermal contact and inhalation) were calculated and the individual values of HQ and HI of these HMs for children and adults are presented in Table 8. but their dermal posed less risk compared to children. Moreover, it was found that ingestion and inhalation routes were found insignificant for $\mathrm{Cd}$ exposure both in children and adults while dermal contact for $\mathrm{Ni}$ proved to be insignificant route for the same receptor groups based on the HQ values.

The HI values of the HMs for both the receptor groups declined in the order of $\mathrm{Cr}>\mathrm{Pb}>\mathrm{Ni}>\mathrm{Cd}$. Adults displayed higher $\mathrm{HI}$ values for $\mathrm{Cr}, \mathrm{Ni}$ and $\mathrm{Pb}$ than children while the HI values were comparable for $\mathrm{Cd}$ between them. Among the HMs determined for non-carcinogenic health risk, Cr contributed 95\% of the $\mathrm{HI}$ in children, while $85 \%$ contribution of the HI was found in adults for the same element similar to recent works of Liu et al., [56]. They also reported non-carcinogenic risk due to high concentration of $\mathrm{Cr}$ in the road dust of Changsa city of China. Above all, the $\mathrm{HI}$ values calculated for $\mathrm{Cd}, \mathrm{Cr}, \mathrm{Ni}$ and $\mathrm{Pb}$ (Table 8) for both children and adults were less the

Table 8: Comparison of non-carcinogenic health risks posed by the heavy metals (HMs) in adults and children

\begin{tabular}{lllllllll}
\hline \multirow{2}{*}{$\begin{array}{l}\text { He avy } \\
\text { metals }\end{array}$} & \multicolumn{2}{c}{$\mathbf{H Q}_{\text {ingest }}$} & \multicolumn{2}{c}{ HQ $_{\text {dermal }}$} & \multicolumn{2}{c}{ HQ $_{\text {inhale }}$} & \multicolumn{2}{c}{ HI } \\
\cline { 2 - 9 } & Child & Adult & Child & Adult & Child & Adult & Child & Adult \\
\hline $\mathrm{Cd}$ & $2.36 \times 10^{-6}$ & $2.41 \times 10^{-7}$ & $2.76 \times 10^{-6}$ & $1.73 \times 10^{-7}$ & $2.09 \times 10^{-7}$ & $4.43 \times 10^{-6}$ & $5.32 \times 10^{-6}$ & $4.84 \times 10^{-6}$ \\
$\mathrm{Cr}$ & $1.40 \times 10^{-4}$ & $5.02 \times 10^{-3}$ & $4.10 \times 10^{-4}$ & $2.56 \times 10^{-5}$ & $1.29 \times 10^{-3}$ & $2.75 \times 10^{-2}$ & $1.84 \times 10^{-3}$ & $2.75 \times 10^{-2}$ \\
$\mathrm{Ni}$ & $1.50 \times 10^{-5}$ & $1.53 \times 10^{-6}$ & $3.25 \times 10^{-6}$ & $2.03 \times 10^{-7}$ & $1.29 \times 10^{-6}$ & $2.73 \times 10^{-5}$ & $1.95 \times 10^{-5}$ & $2.90 \times 10^{-5}$ \\
$\mathrm{~Pb}$ & $4.94 \times 10^{-5}$ & $1.42 \times 10^{-5}$ & $1.90 \times 10^{-5}$ & $1.18 \times 10^{-6}$ & $4.37 \times 10^{-6}$ & $9.28 \times 10^{-5}$ & $7.27 \times 10^{-5}$ & $5.01 \times 10^{-3}$ \\
\hline
\end{tabular}

The HQ and HI values of all metals were below 1, demonstrating no risk of non-carcinogenic impacts among children and adults residing in the territory of Kathmandu. The HQ values of the HMs through all the three exposure pathways were found to be in the order of $\mathrm{Cr}>\mathrm{Pb}>\mathrm{Ni}>\mathrm{Cd}$ for both the receptor groups. Further, the results also showed that children had comparatively higher HQ values of the HMs for ingestion and dermal contact pathways than adults while HQ values were found higher for inhalation route in adults. The higher HQ values of the HMs in children through ingestion pathway can be attributed to the more vulnerability of children to the toxic substances. In addition, children are also more sensitive to heavy metals in indoor dust due to their behaviour such as hand-to-mouth activities, crawling and fast growth rate [12,54]. Moreover, Olujimi et al. [55] also reported ingestion as the main toxic metal exposure route for children as they prefer to play on the house floor and ingest the indoor dust indirectly. Among the HMs, Cr displayed higher HQ for the ingestion and inhalation pathways for adults maximum permissible value of 1.0 which indicates no non-carcinogenic risks in the receptor groups. The findings are in agreement with the risk assessment conducted by Kurt-Karakus [46], Ardashiri and Hashemi [49], Olujimi et al. [55], and Liu et al. [56], who also reported the total hazard quotient ( $\Sigma \mathrm{HQ})$ less than the acceptable level of 1 , indicating that exposure to heavy metals in indoor dust poses no noncarcinogenic risks to children and adults.

\section{Carcinogenic risk}

The calculated LCR values for each exposure pathway and TLCR in children and adults are listed in Table 9.

For children and adults, the LCR values through all the three exposure pathways decreased in the order of $\mathrm{Ni}>\mathrm{Cr}>\mathrm{Cd}>\mathrm{Pb}$. The obtained LCR data suggest that exposure through ingestion in children was comparably a more dangerous route of exposure to these metals followed by dermal contact and inhalation. However, LCR values for adults were found in the order of inhalation $>$ ingestion $>$ dermal contact. Further, it was found that almost all calculated LCR values of the HMs for all the three 
Table 9: Comparison of carcinogenic health risks posed by the heavy metals (HMS) in adults and children

\begin{tabular}{lllllllll}
\hline \multirow{2}{*}{$\begin{array}{c}\text { Heavy } \\
\text { metals }\end{array}$} & \multicolumn{2}{c}{$\mathbf{L C R}_{\text {ingest }}$} & \multicolumn{2}{c}{ LCR $_{\text {dermal }}$} & \multicolumn{2}{c}{ LCR $_{\text {inale }}$} & \multicolumn{2}{c}{ TLCR } \\
\cline { 2 - 8 } & Child & Adult & Child & Adult & Child & Adult & Child & Adult \\
\hline $\mathrm{Cd}$ & $1.49 \times 10^{-8}$ & $1.52 \times 10^{-9}$ & $8.69 \times 10^{-10}$ & $5.47 \times 10^{-11}$ & $1.32 \times 10^{-9}$ & $2.79 \times 10^{-8}$ & $1.71 \times 10^{-8}$ & $2.95 \times 10^{-8}$ \\
$\mathrm{Cr}$ & $2.10 \times 10^{-7}$ & $2.14 \times 10^{-8}$ & $1.23 \times 10^{-8}$ & $7.70 \times 10^{-10}$ & $1.86 \times 10^{-8}$ & $3.94 \times 10^{-7}$ & $2.41 \times 10^{-7}$ & $4.16 \times 10^{-7}$ \\
$\mathrm{Ni}$ & $1.32 \times 10^{-6}$ & $1.58 \times 10^{-7}$ & $7.74 \times 10^{-8}$ & $4.84 \times 10^{-9}$ & $1.17 \times 10^{-7}$ & $2.48 \times 10^{-6}$ & $1.51 \times 10^{-6}$ & $2.64 \times 10^{-6}$ \\
$\mathrm{~Pb}$ & $1.47 \times 10^{-9}$ & $1.50 \times 10^{-10}$ & $8.59 \times 10^{-11}$ & $5.36 \times 10^{-12}$ & $1.30 \times 10^{-10}$ & $2.76 \times 10^{-9}$ & $1.69 \times 10^{-9}$ & $2.92 \times 10^{-9}$ \\
\hline
\end{tabular}

exposure routes were less than $10^{-6}$ indicating falls of the risk factor.

Total lifetime cancer risks (TLCR) for both children and adults also declined in the order of $\mathrm{Ni}>\mathrm{Cr}>\mathrm{Cd}$ $>\mathrm{Pb}$. However, the TLCR values of these metals were comparable between the receptor groups. Further, it was found that $\mathrm{Ni}$ and $\mathrm{Cr}$ contributed $86 \%$ and $14 \%$ of the TLCR in adults respectively while similar contribution of $\mathrm{Ni}(85 \%)$ and $\mathrm{Cr}(14 \%)$ was also found in children. The acceptable safe limit of TLCR for carcinogenic risk is in the range of $1 \times 10^{-6}-1 \times 10^{-4}$ [23]. Since both children and adults did not exceed the risk range, this implies that carcinogenic risks did not exist and the potential carcinogenic effect would unlikely to occur in both the receptor groups. The results of the present carcinogenic risk assessment are also in agreement with Lin et al, [45], Kurt-Karakus [46] and Olujimi et al, [55] who also reported carcinogenic risk for these heavy metals within the acceptable level $\left(10^{-4}-10^{-6}\right)$ for the receptor groups.

The exposure parameters of a population are dominant factor in health risk assessment that greatly vary according to a geographical region and nationality $[57,58]$. The risk assessment results may not be easily comparable between studies unless there are uniform standards for exposure parameters $[59,60]$. In this context, Nepal does not possess any standard reference in terms of exposure parameters till today nor does it resemble with many parameters derived from western countries due to differences in race and region. Such unpleasant circumstances may cause large deviations in the health risk assessment, even at greater accuracy of the measured concentrations.

\section{Conclusion}

This study presents a comprehensive evaluation of indoor environment in Kathmandu, Nepal by evaluating the distribution of selected heavy metals in indoor household dust from different types of land use zones viz., commercial, heavy traffic, residential and control. The overall mean concentrations of $\mathrm{Cd}$, $\mathrm{Cr}, \mathrm{Ni}$ and $\mathrm{Pb}$ in indoor dust exceeded the control values as well as the average world's shale values. In indoor dust samples from all land use zones, $\mathrm{Cr}$ demonstrated the highest concentration whereas $\mathrm{Cd}$ was found to be the lowest of all. The present study recorded exceptionally high $\mathrm{Cr}$ content in indoor dust samples compared to other cities/countries.

The indoor environmental status of Kathmandu was assessed on the basis of two pollution indices viz., contamination factor (CF) and pollution load index (PLI). Accordingly, CF values were found to vary from moderate to considerable degree of metal contamination in indoor dust. Of the four types of HMs analyzed, only Ni demonstrated considerable level of contamination in indoor dust samples from commercial and heavy traffic zones. The average metal contamination level in Kathmandu indoor dust was at considerable level for $\mathrm{Ni}(\mathrm{CF}=3.45)$ and moderate level for $\mathrm{Cd}(\mathrm{CF}=2.28), \mathrm{Cr}(\mathrm{CF}=2.07)$ and $\mathrm{Pb}(\mathrm{CF}=1.72)$. Similarly, PLI value was greater than 1, implying a category of polluted indoor dust from all land use zones. The metal contamination level in indoor dust samples based on PLI values followed the decreasing order of heavy traffic (PLI = 6.90) $>$ commercial $(\mathrm{PLI}=5.16)>$ residential $(\mathrm{PLI}=$ $3.75)$ zone. The high PLI could be attributable to the cumulative concentrations of heavy metals in all land use zones, implying an alarming condition

An assessment of health risk showed that ingestion was the main exposure pathway for these HMs in children followed by inhalation and dermal contact while adults displayed inhalation as the main route followed by ingestion and dermal contact. For noncarcinogenic health risk, both HQ and HI values were below 1.0 indicating no adverse health risk for both the receptor groups. However, Cr contributed 95\% and $85 \%$ of the $\mathrm{HI}$ in children and adults respectively. For carcinogenic health risk, the calculated values of lifetime cancer risk (LCR) for individual exposure route and total lifetime cancer risk (TLCR) were found within the acceptable safe limit of $1 \times 10^{-6}$ $1 \times 10^{-4}$ indicating no cancer risk for both the receptor groups. Nevertheless, Ni prevailed $85 \%$ and $86 \%$ 
as major contributions for TLCR in children and adults respectively. However, the study indicated vulnerability of both the receptor groups to the risks of indoor dust metals. Hence, it can be concluded from the present study that a monitoring plan is necessary to assess potential sources of heavy metals evolution in indoor dust from different land use zones in order to develop proper measures for reducing the exposure risk to human health through all possible routes.

\section{Acknowledgments}

The authors gratefully acknowledge Department of Applied Chemistry, BHU, Varanasi, India for FAAS analysis and Padma Kanya Multiple Campus, Tribhuvan University, Kathmandu for providing laboratory facilities.

\section{References}

1. G. Žibret, D. Van Tonder and L. Žibret, Metal content in street dust as a reflection of atmospheric dust emissions from coal power plants, metal smelters, and traffic, Environmental Science and Pollution Research, 2013, 20(7), 4455-4468. (DOI:10.1007/ s11356-012-1398-7)

2. A.TurnerandL. Simmonds, Elemental concentrations and metal bio-accessibility in UK household dust, Science of the Total Environment, 2016, 371(1-3), 74-81. (DOI: 10.1016/j.scitotenv.2006.08.011)

3. A. D. Bhanakar, D. G. Gajghate, P. S. Rao and P. Nema, Inventory of $\mathrm{SO}_{2}, \mathrm{PM}$ and toxic metals emissions from industrial sources in greater Mumbai, India, Atmospheric Environment, 2005, 39(21), 3851-3864. (DOI: 10.1016/j.atmosenv.2005.02.052)

4. Y. Yang, H. Liao and S. Lou, Decadal trend and inter annual variation of outflow of aerosols from East Asia: Roles of variations in meteorological parameters and emissions, Atmospheric Environment, 2015, 100, 141-153. (DOI:10.1016/j.atmosenv.2014.11.004)

5. H. Yongming, D. Peixuan, C. Junji and E. S. Posmentier, Multivariate analysis of heavy metal contamination in urban dusts of Xi' an, Central China, Science of the Total Environment, 2006, 355(1), 176186. (DOI: 10.1016/j.scitotenv.2005.02.026)

6. R. K. Aryal, H. Furumai, F. Nakajima and M. A. Hossain, Vertical distribution and speciation of heavy metals in stormwater infiltration facilities: possible heavy metals release to groundwater, Water Practice and Technology, 2007, 2(2), wpt2007052. (DOI: 10.2166/wpt.2007.052)

7. G. Shi, Z. Chen, C. Bi, Y. Li, J. Teng, L. Wang and $\mathrm{S}$. $\mathrm{Xu}$, Comprehensive assessment of toxic metals in urban and suburban street deposited sediments (SDSs) in the biggest metropolitan area of China,
Environmental Pollution, 2010, 158(3), 694-703. (DOI: 10.1016/j.envpol.2009.10.020)

8. D. Meza-Figueroa, M. D. La O-Villanueva and M. L. D. Parra, Heavy metal distribution in dust from elementary schools in Hermosillo, Sonora, Mexico, Atmospheric Environment, 2007, 41(2), 276-288. (DOI: 10.1016/j.atmosenv.2006.08.034)

9. F. M. Darus, R. A. Nasir, S. M. Sumari, Z. S. Ismail and N. A. Omar, Heavy metals composition of indoor dust in nursery schools building. ProcediaSocial and Behavioral Sciences, 2012, 38, 169-175. (DOI: 10.1016/j.sbspro.2012.03.337)

10. D. Shi and X. Lu, Accumulation degree and source apportionment of trace metals in smaller than 63 $\mu \mathrm{m}$ road dust from the areas with different land uses: A case study of Xi'an, China, Science of the Total Environment, 2018, 636, 1211-1218. (DOI: 10.1016/j.scitotenv.2018.04.385)

11. F. Li, J. Zhang, J. Huang, W. Jiang, C. Liu, Z. Zhang, C. Zhang and G. Zeng, Spatial health risk assessment and hierarchical risk management for mercury in soils from a typical contaminated site, China, Environmental Geochemistry and Health, 2017, 39(4), 923-934. (DOI: 10.1007/s10653-0169864-7)

12. G. Goudarzi, S. M. Daryanoosh, H. Godini, P. K. Hopke, P. Sicard, A. De Marco, H. D. Rad, A. Harbizadeh, F. Jahedi, M. J. Mohammadi and J. Savari, Health risk assessment of exposure to the Middle-Eastern Dust storms in the Iranian megacity of Kermanshah, Public Health, 2017, 148, 109-116. (DOI: 10.1016/j.puhe.2017.03.009)

13. USEPA, Supplemental guidance for developing soil screening levels for superfund sites. OSWER 9355/4-24, 2002, Washington, DC: Office of Emergency and Remedial Response.

14. D. T. Tran, L. Y. Alleman, P. Coddeville and J. C. Gallo, Elemental characterization and source identification of size resolved atmospheric particles in French classrooms, Atmospheric Environment, 2012, 54, 250-259. (DOI: 10.1016/j. atmosenv.2012.02.021)

15. WHO, Household air pollution and health, 2018, Retrieved on 11 September, 2019 from https://www. who.int/news-room/fact-sheets/detail/householdair-pollution-and-health

16. WHO Global Urban Ambient Air Pollution Database, World Health Organization, 2016, Retrieved on 4 April 2019 from https://www.who. int/phe/health_topics/outdoorair/databases

17. Ambient (outdoor) air quality and health, World Health Organization, 2014, Retrieved on 4 April 2019 from https://www.who.int/airpollution/ ambient/health-impacts/en.

18. H. Zhao and X. Li, Understanding the relationship between heavy metals inroad-deposited sediments 
and wash-off particles in urban stormwater using simulated rainfall, Journal of Hazardous Materials, 2013, 246, 267-276. (DOI: 10.1016/j. jhazmat.2012.12.035)

19. V. F. Shilton, C. A. Booth, J. P. Smith, P. Giess, D. J. Mitchell and C. D. Williams, Magnetic properties of urban street dust and their relationship with organic matter content in the West Midlands, UK, Atmospheric Environment, 2005, 39(20), 36513659. (DOI: 10.1016/j.atmosenv.2005.03.005)

20. S. Roy, S. K. Gupta, J. Prakash, G. Habib, K. Baudh and M. Nasr, Ecological and human health risk assessment of heavy metal contamination in road dust in the National Capital Territory (NCT) of Delhi, India. Environmental Science and Pollution Research, 2019, 26(29), 30413-30425. (DOI: 10.1007/s11356-019-06216-5)

21. L. Hakanson, An ecological risk index for aquatic pollution control. A sedimentological approach, Water Research, 1980, 14(8), 975-1001.

22. D. L. Thomlinson, J. G. Wilson, C. R. Harris and D.W. Jeffrey, Problems in the assessment of heavy metal levels in estuaries and the formation of a pollution index, Helgoland Marine Research, 1980, 33(1-4), 566-575. (DOI: 10.1007/BF02414780)

23. USEPA, Soil screening guidance: technical background document. EPA/540/R-95/128, 1996, Office of Solid Waste and Emergency Response.

24. USEPA, Baseline human health risk assessment, 2001, Vasquez Boulevard and I-70 superfund site Denver, Denver (Co).

25. USEPA, United States Environmental Protection Agency, 2010, USEPA Regional Screening Level Table.

26. OME, Soil investigation and human health risk assessment for the Rodney street community. 2000, Port Colborne, Ontario: OMN, Ontario Ministry of the Environment, Canada.

27. USEPA, Risk Assessment Guidance for Superfund. Volume I: Human Health Evaluation Manual (Part A). EPA/540/1-89/002, 1989.

28. X. Hu, Y. Zhang, J. Luo, T. Wang, H. Lian and Z. Ding, Bioaccessibility and health risk of arsenic, mercury and other metals in urban street dusts from a mega-city, Nanjing, China. Environmental Pollution, 2011,159(5), 1215-1221. (DOI: 10.1016/j. envpol.2011.01.037)

29. E. Staff, Supplemental guidance for developing soil screening levels for superfund sites, peer review draft. US Environmental Protection Agency Office of Solid Waste and Emergency Response, 2001, OSWER, Washington, DC. 9355.4-24.

30. Z. Li, Z. Ma, T. J. van der Kuijp, Z. Yuan and L. Huang, A review of soil heavy metal pollution from mines in China: pollution and health risk assessment, Science of the Total Environment, 2014, 468, 843-
853. (DOI: 10.1016/j.scitotenv.2013.08.090)

31. N. Zheng, J. Liu, Q. Wang and Z. Liang, Health risk assessment of heavy metal exposure to street dust in the zinc smelting district, Northeast of China, Science of the Total Environment, 2010, 408(4), 726733. (DOI: 10.1016/j.scitotenv.2009.10.075)

32. K. K. Turekian and K. H. Wedepohl, Distribution of the elements in some major units of the earth's crust, Geological Society of America Bulletin, 1961， 72(2), 175-192. (DOI: 10.1130/0016-7606(1961)72[175:DOTEIS]2.0. $\mathrm{CO} ; 2)$

33. E. Sabzevari and S. Sobhanardakani, Analysis of selected heavy metals in indoor dust collected from city of Khorramabad, Iran: A case study, Jundishapur Journal of Health Sciences, 2018, 10(3), e67382. (DOI: 10.5812/jjhs.67382)

34. A. Ghani and A Ghani, Effect of chromium toxicity on growth, chlorophyll and some mineral nutrients of brassica juncea L., Egyptian Academic Journal of Biological Sciences, H. Botany, 2011, 2(1), 9-15. (DOI: 10.21608/eajbsh.2011.17007)

35. O. A. Al-Khashman, Heavy metal distribution in dust, street dust and soils from the work place in Karak Industrial Estate, Jordan, Atmospheric Environment, 2004, 38(39), 6803-6812. (DOI: 10.1016/j.atmosenv.2004.09.011)

36. M. S. Akhter and I. M. Madany, Heavy metals in street and house dust in Bahrain, Water, Air, and Soil Pollution, 1993, 66(1-2), 111-119. (DOI: 10.1007/ BF00477063)

37. T. K. Rout, R. E. Masto, L. C. Ram, J. George and P. K. Padhy, Assessment of human health risks from heavy metals in outdoor dust samples in a coal mining area, Environmental Geochemistry and Health, 2012, 35(3), 347-356. (DOI: 10.1007/ s10653-012-9499-2)

38. J. Q. Yuen, P. H. Olin, H. S. Lim, S.G. Benner, R. A. Sutherland and A. D. Ziegler, Accumulation of potentially toxic elements in road deposited sediments in residential and light industrial neighborhoods of Singapore, Journal of Environmental Management, 2012, 101, 151-163. (DOI: 10.1016/j.jenvman.2011.11.017)

39. U. Divrikli, M. Soylak, L. Elci and M. Dogan, The investigation of trace metal concentrations in the street dust samples collected from Kayseri, Turkey, Journal of Trace and Microprobe Techniques, 2003, 21(4), 713-720. (DOI: 10.1081/TMA-120025821)

40. C. S. Tamrakar and P. R. Shakya, Assessment of heavy metals in street dust in Kathmandu Metropolitan City and their possible impacts on the environment, Pakistan Journal of Analytical \& Environmental Chemistry, 2011, 12(1\&2), 32-41. http://pjaec.pk/index.php/pjaec/article/view/145

41. M. T. Puth, M. Neuhäuser and G. D. Ruxton, 
Effective use of Pearson's product-moment correlation coefficient, Animal Behaviour, 2014, 93, 183-189. (DOI: 10.1016/j.anbehav.2014.05.003)

42. G. J. Komarnicki, Lead and cadmium in indoor air and the urban environment, Environmental Pollution, 2005, 36(1), 47-61. (DOI: 10.1016/j. envpol.2004.12.006)

43. S. K. M. Hassan, Metal concentrations and distribution in the household, stairs and entryway dust of some Egyptian homes, Atmospheric Environment, 2012, 54, 207-215. (DOI: 10.1016/j. atmosenv.2012.02.013)

44. M. T. Latif, M. Y. Saw, A. Saad, N. Mohamad, N. H. Baharuddin, M. B. Mokhtar and N. M., Composition of heavy metals in indoor dust and their possible exposure: a case study of preschool children in Malaysia, Air Quality, Atmosphere \& Health, 2014, 7(2), 181-193. (DOI: 10.1007/s11869-013-0224-9)

45. Y. Lin, F. Fang, F. Wang and M. Xu, Pollution distribution and health risk assessment of heavy metals in indoor dust in Anhui rural, China, Environmental Monitoring and Assessment, 2015, 187(9), 565. (DOI: 10.1007/s10661-0154763-4)

46. P. B. Kurt-Karakus, Determination of heavy metals in indoor dust from Istanbul, Turkey: Estimation of the health risk, Environmental International, 2012, 50, 47-55. (DOI: 10.1016/j.envint.2012.09.011)

47. O. A. Madanat, A. Jiries, M. Batarseh and F. A. Nasir, Indoor and outdoor pollution with heavy metals in Al-Karak City, Environmental Application \& Science, 2017, 12(2), 131-139.

48. N. Boisa and B. Odagwe, Indoor dust-based pollution status and risk assessment for a rural town, Ebedei in Nigeria hosting gas flare facility, Journal of Environmental Protection, 2019, 10, 208-220. (DOI: 10.4236/jep.2019.102012)

49. A. Ardashiri and S. E. Hashemi, Health risk assessment of heavy metals in indoor dust from Bushehr, Iran, Iranian Journal of Health, Safety and Environment, 2018, 5(2), 966-971.

http://ijhse.ir/index.php/IJHSE/article/view/302

50. A. Pitawala, D. Herath and N. Piyatunga, Chemical characterization of household dust in two major cities: Colombo, the capital and Kandy, the hill capital, Sri Lanka, Carpathian Journal of Earth and Environmental Sciences, 2013, 8(2), 89-95.

51. J. Nnaji, Assessment of heavy metal contamination of agricultural soils and cassava leaves along Umuahia-Ikot-Ekpene highway, Abia state, Research Journal of Pharmaceutical, Biological and Chemical Sciences, 2015, 6(2), 301-304.
52. S. Dehghani, F. Moore, B. Keshavarzi and A. H. Beverley, Health risk implications of potentially toxic metals in street dust and surface soil of Tehran, Iran, Ecotoxicology and Environmental Safety, 2017, 136, 92-103. (DOI: 10.1016/j. ecoenv.2016.10.037)

53. M. R. Mehr, B. Keshavarzi, F. Moore, R. Sharifi, A. Lahijanzadeh and M. Kermani, Distribution, source identification and health risk assessment of soil heavy metals in urban areas of Isfahan province, Iran, Journal of African Earth Sciences, 2017, 132, 16-26. (DOI: 10.1016/j.jafrearsci.2017.04.026)

54. S. Jena and G. Singh, Human health risk assessment of airborne trace elements in Dhanbad, India, Atmospheric Pollution Research, 2017, 8(3), 490502. (DOI: 10.1016/j.apr.2016.12.003)

55. O. Olujimi, O. Steiner and W. Goessler, Pollution indexing and health risk assessments of trace elements in indoor dusts from classrooms, living rooms and offices in Ogun State, Nigeria, Journal of African Earth Sciences, 2015, 101(1), 396-404. (DOI: 10.1016/j.jafrearsci.2014.10.007)

56. P. Liu, Y. Lei, H. Ren, J. Gao, H. Xu, Z. Shen, Q. Zhang, C. Zheng, H. Liu, R. Zhang and H. Pan, Seasonal variation and health risk assessment of heavy metals in $\mathrm{PM}_{2.5}$ during winter and summer over Xi'an, China, Atmosphere, 2017, 8(5), 91. (DOI: 10.3390/atmos8050091)

57. A. Jayarathne, P. Egodawatta, G. A. Ayoko and A. Goonetilleke, Assessment of ecological and human health risks of metals in urban road dust based on geochemical fractionation and potential bioavailability, Science of the Total Environment, 2018, 635, 1609-1619. (DOI: 10.1016/j. scitotenv.2018.04.098)

58. H. Khademi, M. Gabarron, A. Abbaspour, S. Martinez-Martinez, A. Faz and J. A. Acosta, Environmental impact assessment of industrial activities on heavy metals distribution in street dust and soil, Chemosphere, 2019, 217, 695-705. (DOI: 10.1016/j.chemosphere.2018.11.045)

59. Z. Cheng, L. J. Chen, H. H. Li, J. Q. Lin, Z. B. Yang and Y. X. Yang, Characteristics and health risk assessment of heavy metals exposure via household dust from urban area in Chengdu, China, Science of the Total Environment, 2018, 619, 621-629. (DOI: 10.1016/j.scitotenv.2017.11.144)

60. M. Lian, J. Wang, L. Sun, Z. Xu, J. Tang, J. Yan and $X$. Zeng, Profiles and potential health risks of heavy metals in soil and crops from the watershed of Xi River in Northeast China, Ecotoxicology and Environmental Safety, 2019, 169, 442-448. (DOI: 10.1016/j.ecoenv.2018.11.046) 